SF 509

.562

Copy 1
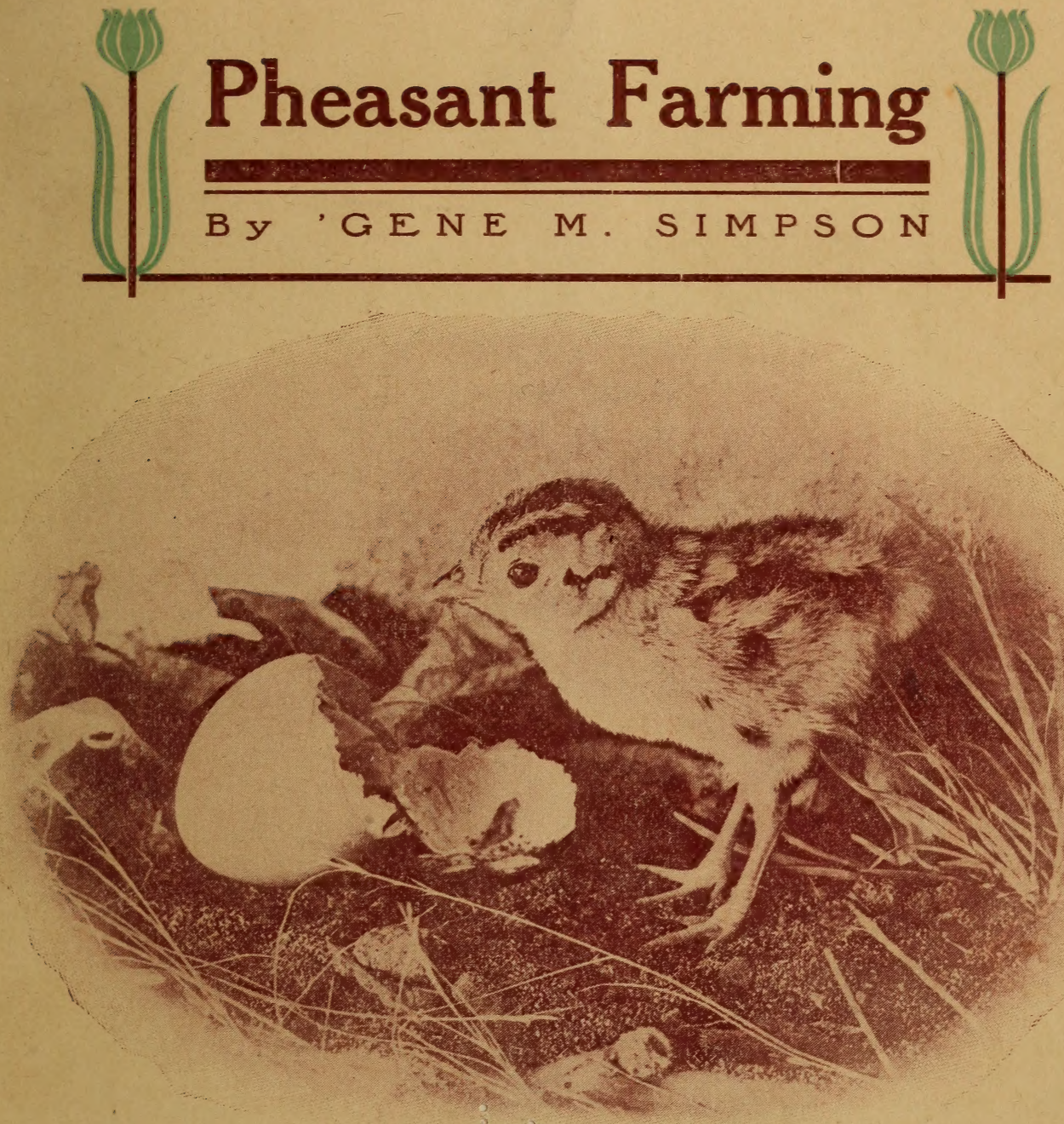

(U) SIMPSON'S PHEASANT FARM

CORVALLIS, OREGON, U. S. A.

Price Twenty-five Cents 


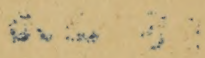

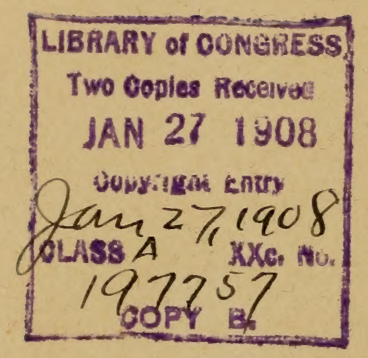

Copyrighted 1908

By 'Gene M. Simpson

Corvallis, Oregon

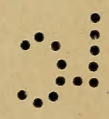




\section{Pheasant Farming}

General Information About Pheasants With Instructions How to Raise Them

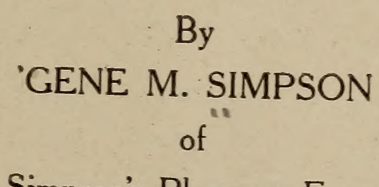

Corvallis, Oregon

1908

Press of

Benton County Republican

Corvallis, Oregon 


$$
5=5.5^{109}
$$

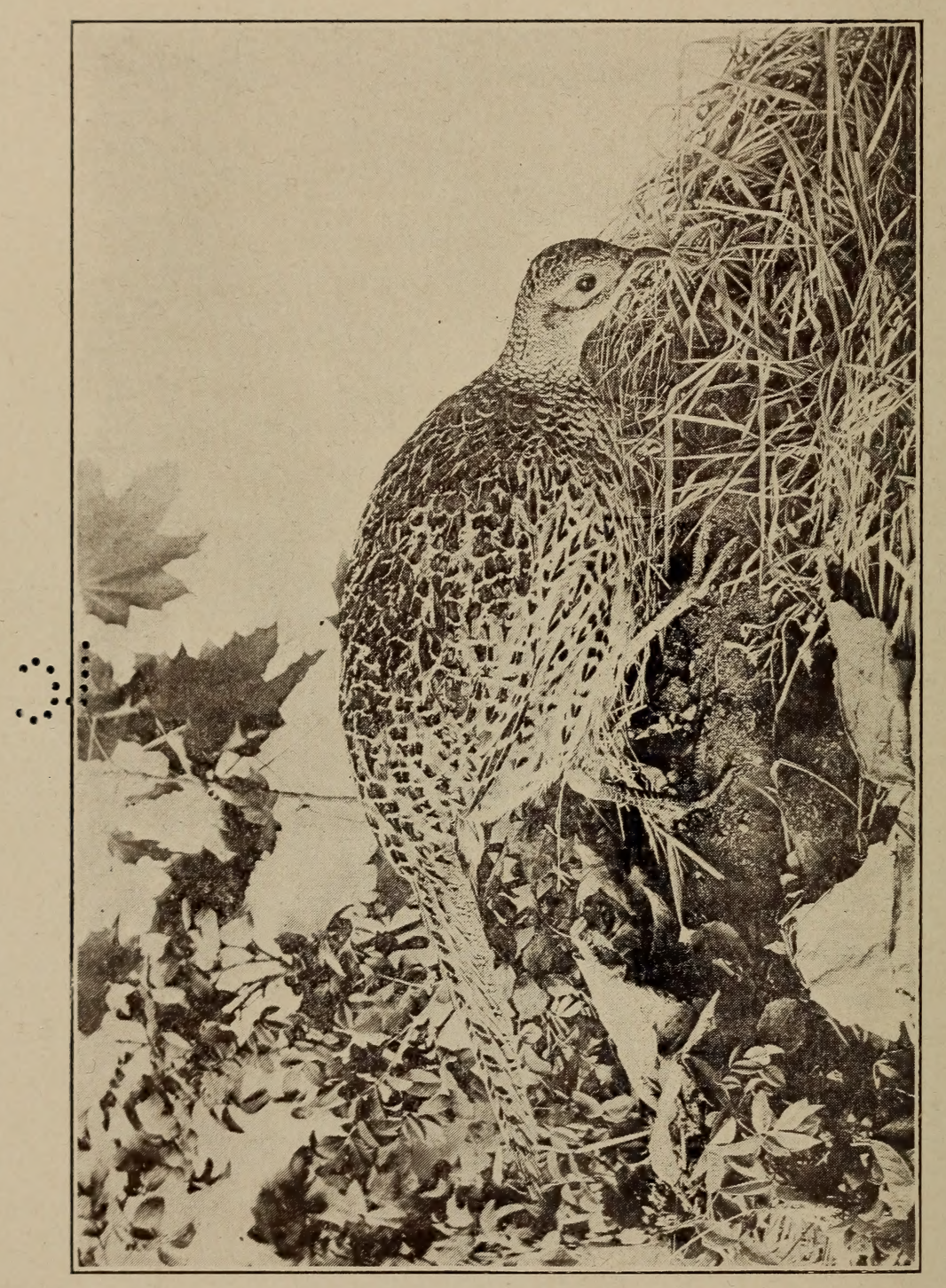

के

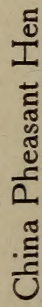




\section{Foreword.}

I Every person to whom I have sold pheasants or eggs, has written me for information, either as to the nature of the birds or how to raise them. It has been my desire to answer these inquiries in full that my patrons might have the benefit of whatever knowledge I might have obtained on the subject, and profit by my experience in raising pheasants. These inquiries have been so varied that it has been impracticable to answer them by let.er, and hence I have ventured to prepare this booklet. There are many ways of raising pheasants, just as there are many ways of raising chickens. The methods described in the pages to follow are not contended to be the only ways, but they are methods the writer has followed with success, and therefore recommends as a "good way."

II This booklet is offered with the hope that after reading it, someone may be encouraged to take up the breeding of pheasants either for pleasure or profit, or that those already so engaged may be assisted in their work.

\section{'GENE M. SIMPSON}

Simpson's Pheasant Farm

Corvallis, Oregon 


\section{Pheasants}

There are many varieties of pheasants but for practical purposes they may be divided into two general classes, (1) those used as game, and (2) those used exclusively for show and ornamentation. In the first class there are three principal varieties: the Chinese, English Ring-neck and Common or English Black-neck. Other varieties closely allied to these are the Japanese, Mongolian, Reeves, Hagenbeck, Prince of Wales, Somerings; but the three kinds first named are by far the most prominent game varieties. The latter named pheasants are reared for their beautiful plumage, the Japanese and Reeves being the most common. The Mongolian comes from the interior of China, and there are perhaps not a dozen true Mongolian pheasants in America. All of the pheasants above named are true pheasants of which the generica acientific name is Phasianus. The Golden, Amherst and Silver are called pheasants, and, while almost identical in nature and requiring the same treatment, yet are not true pheasants.

The Chinese Pheasant (Phasianus torquatus) and the Common or English Black-neck pheasant (Phasianus Colchicus) are each separate and distinct varieties of pheasants, while the English Ring-neck is a hybrid of the two. This latter bird, English Ring-neck, is the common pheasant of England today and by far the most common variety met with in the United States. It is frequently confounded with the Chinese. The 
English Black-neck pheasant is in general nature and form the same as the Chinese, differing in this that the English Black-neck is of a general mahogany red cast and has no ring around the neck, while the Chinese is lighter and brighter in color and has a silky white ring or band around the neck. The English Ring-neck retains the mahogany red cast, though not so pronounced as the English Black-neck, and has the white collar of the Chinese, hence the name English Ring-neck, indicating the combination of these two differences.

The old English Black-neck was probably introduced into England before the Norman Conquest. There is a record of the birds being served as early as A. D. 1059, but now they have so interbred with the Chinese that it is difficult to find a pure specimen. Those on my farm are from imported stock and religiously kept by themselves.

The pure Chinese pheasant is the game bird par excellence. Taken all in all, it is a serious question whether or not he has any superior as an all around game bird. It is utter folly to hunt them without a dog. Their ability to conceal themselves, even in the scantiest cover, is wonderful. Without a dog it is not uncommon to pass within ten feet of one hidden in the grass, without his rising. When running in cover they move very swiftly with the body close to the ground and possess the ability to pass through grass, short or tall. without disturbing the surface. When overtaken by the dog, they will lie well, and this fact combined with the further fact that they 
are always found in the open, makes pheasant shooting the cleanest bird shooting in the world.

Possessed of remarkable vitality, they do not succumb to slight gunshot wounds. Being clean limbed, with powerful thighs, they are exceptionally fleet on foot, and if winged only, the pheasant falls running, and here the dog is put to his severest test. Very few dogs can track a crippled Chinaman their first season, but an experienced setter or pointer learns to recognize the wounded birds and endeavors to be as near him as possible when he touches the ground.

Besides his gameiness and delicate flesh, he is unquestionably one of the most ornamental of the game birds. He is a native of the northern part of China, being found as far north as the Amour and as far south as Shanghai. The question is often asked if the Chinese pheasant can stand the heat and cold. A reference to the map of China will answer the question. The pheasant has succeeded over the larger part of Europe even as far north as Sweden. On this continent it does well in Canada and Nova Scotia but nowhere has its introduction been attended with such prolific results as in the Willamette Valley in the state of Oregon. I do not know which is to be congratulated most, the Willamette Valley for having the beautiful and gamey pheasants, or the pheasants for having been so fortunate as to find so delightful a valley.

It was stated by an eminent authority on pheasants that in 1893 there were more Chinese pheasants in Oregon than in the whole Chinese Empire. Credence 
is lent this statement when it is remembered that it is reliably estimated that in one year 30,000 were killed in one county in this state alone, and the same year 1200 dozen were shipped to the San Francisco market. There could be no better testimonial of the adaptability of the Chinese pheasant as a bird for restocking a state with game than this last statement, which comes irom no less an authority than Judge Denny, the man who intoduced the pheasant into Oregon. For sometime Judge Denny had been United States Consul General at Shanghai and it was from there that he sent the birds to Oregon. The rapidity with which the birds increased in this state is made more marvelous when it is remembered that they were not introduced until 1882 and then only 50 birds were liberated. They were protected absolutely for seven years and thereafter an open season of six weeks was provided, which is now enlarged to two months. If the laws were observed the number of pheasants in Oregon would continue to increase with each year. The rapidity of their increase is doubtless due to the large egg production. It is held by those most familiar with the birds that under ordinary conditions the hen will raise two broods, and in favorable seasons she will care for three broods, in which duties she is assisted by the cock. Thus, in the field, she will lay from 15 to 40 eggs in a season. When in confinement the hen makes small pretense to brood, but will lay more eggs.

What is said of the Chinese Pheasant will apply equally to the English Ring-neck and English Pheasant, 


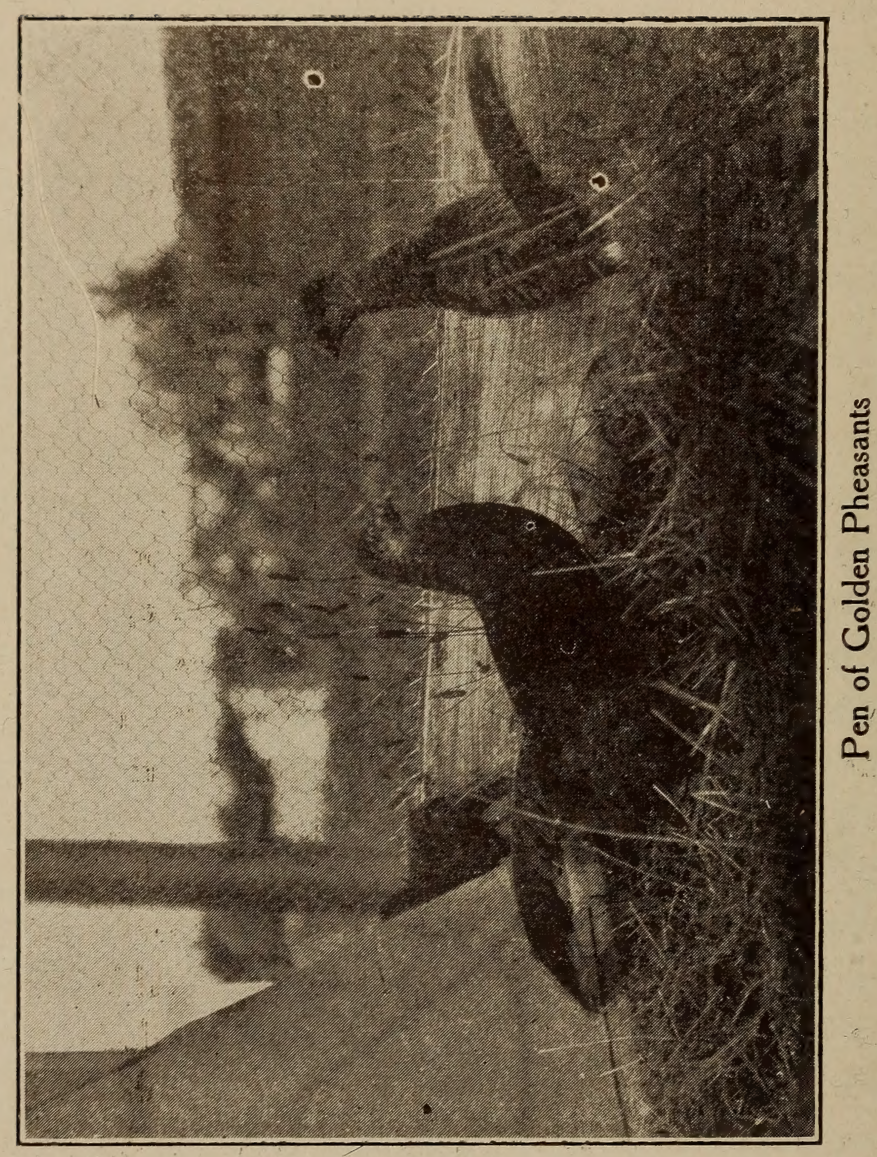

N 
except that the Chinese phsasant is more wild than the other pheasants named, and more beautiful and gamey. In the open the nests are concealed in the tangled grass, but in confinement the eggs are dropped at random, the hens seldom atteuipting to form a nest. Hens may be expected to commence laying about the first of April. The Chinese and English will lay from 50 to 60 eggs in one season, although I have known of a China hen laying as many as 83 eggs in a season, and a customer in Nanaimo, B. C., claims over 180 eggs from two English Ring-neck hens in one year. Golden pheasants will lay from 25 to 30 eggs in one season. The per centage of fertility in all pheasant eggs is remarkably great. It is not at all uncommon for every egg to hatch. One setting of 12 was obtained after the hen had been incubating two weeks. The eggs were carried in a buggy ten miles, placed under a bantam and every egg hatched. The eggs are a greenish gray in color and about the size of a common bantam egg.

In the wild state the pheasant seldom roosts in a tree, and then only in one that is open, so it is in confinement, while they may stay in the shedded part of their pen in the daytime, just at dusk they select a place with an open sky above them in which to pass the night, and this, too, regardless of the inclemency of the weather. They seem to be indifferent to snow and rain and after a night out in the rain, appear none the worse for the drenching. They commonly roost on the ground with feathers drawn down tight to the body.

The young pheasants all have the same plumage until 
about two months old, that of a grayish brown. When a month old it will be noted that the feathers on the back of the neck near the body on some of the young birds will show slightly lighter in color and with a salmon colored cast. These are the hens, the corresponding feathers on the cocks remaining darker and near the color of the remainder of the plumage. When two months old, splotches of chestnut red will begin to appear on the breasts of the cocks. The hens undergo small changes in plumage, and while of a general fawn color, some of the tints shown on her neck are very beautiful. The cocks continue to change color rapidly until at five months they will be in full plumage. Their wealth of color, surpassing the rainbow in variety, gorgeous but delicately blended, beggars description. The artist's brush has never reproduced it, much less can the pen portray an idea of its beauty. Graceful in form, with his splendid robes, the cock Chinese Pheasant is one of the most beautiful birds in existence. The eye never tires of admiring his plumage. He is a source of continual delight to the breeder.

If you can raise turkeys, you can raise pheasants. Like turkeys when matured they are very hardy. The young of the pheasant, like young turkeys, are susceptible to dampness, and should be kept from the wet grass. In fact the similarity between the young pheasant and young turkey is very marked. Some of their calls, particularly one given at nightfall, are almost identical, and in general, treatment adapted to turkeys may safely be applied to pheasants. When young, the birds are tame 
and soon learn to know their keeper. They will become sufficiently familiar to fly upon the keeper's shoulder, or eat out of his hand, but the appearance of a stranger calls for a note of warning to the whole flock. This note is low but quick, and its effect is instantaneous. During the laying season it is not advisable to allow strangers to visit the pens where the pheasants can see them, and better success will be obtained if only one or two persons visit the pheasants, and these should be the ones to feed them. The bird; will be better controlled if the same garments are worn each time, as they instantly detect a change in dress. They will avoid for a day or more anything new placed in their pens. Some breeders place fir boughs or branches of other trees in the pens to offer a hiding place for the pheasants, but it is not at all necessary. The pens described further on provide for a portion being shedded. This applies only to localities where there is considerable rainfall. In drier sections of the country, this shed might be supplanted by a small evergreen tree or two in the pen.

The larger the pens in which your pheasants are kept the better. They are polygamous and four hens and a cock may be kept in a pen 16 feet square. This is a very convenient size, but in any event the birds should each have 50 square feet of ground. It is of advantage to have the pens so arranged that the pheasants may be changed from one pen to the other occasionally. This permits the ground to freshen and it is a good plan to spade up the ground occasionally. A very satisfactory pen for a trio (two hens and a cock) would be 16 feet 


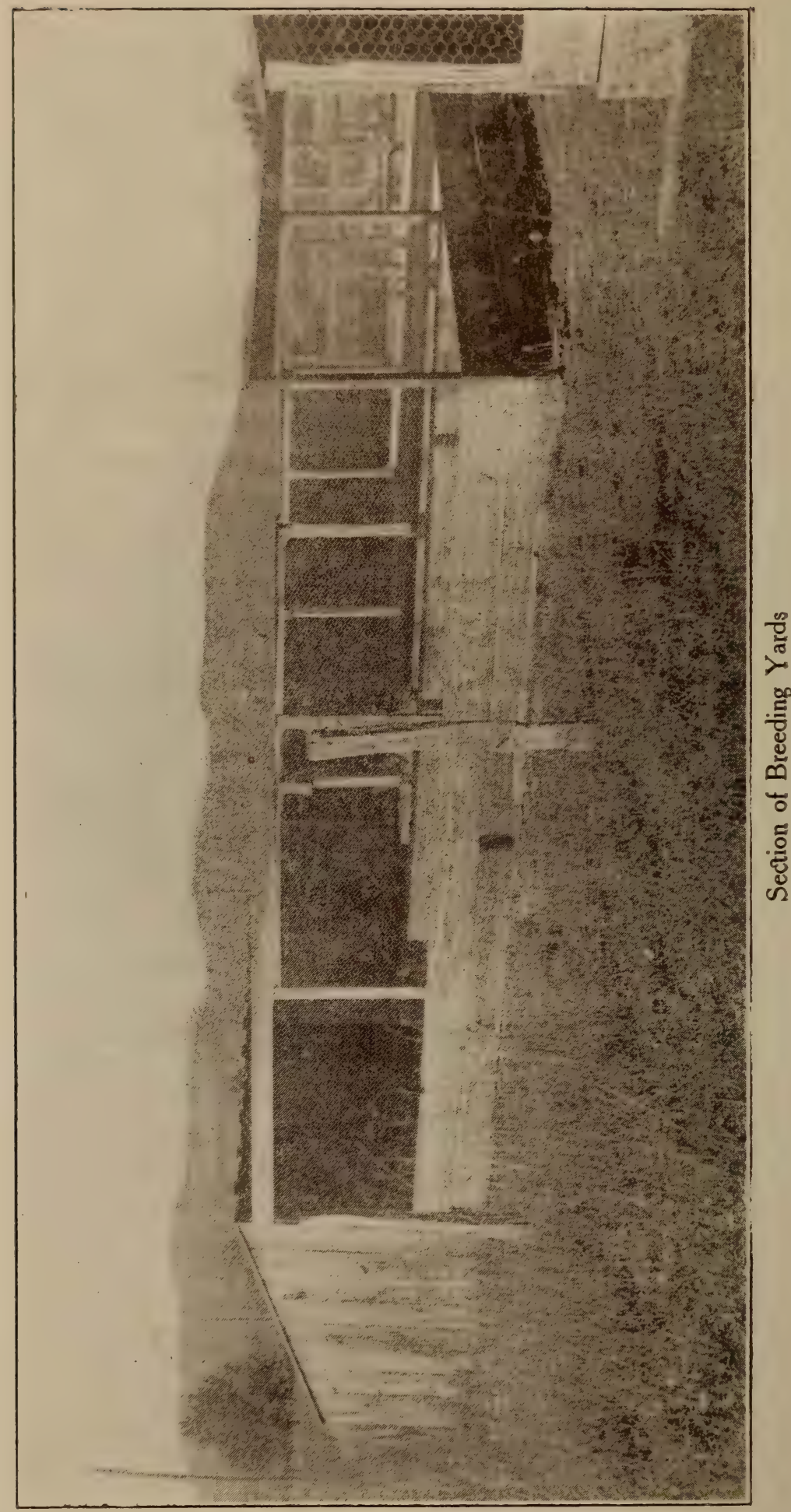


by 32 feet, divided lengthwise with a partition and shedded for 8 feet along one end, the shedded end being so arranged to ward off as much of the storm as possible. Convenient entrances may be arranged and provision should be made that the birds may pass from one pen to another at the keeper's pleasure.

The photograph shows a pen 32 feet wide and 48 feet long divided into six pens each $8 \mathrm{ft}$. by $32 \mathrm{ft}$. The posts are 2 by 4 inches, the two bottom boards each 12 inches wide and the top boards 6 inches wide. The top and sides are of poultry netting. Partitions are built the same as the ends. For old birds the wire used should be a 2-inch poultry netting, but if also to be used in which to keep the young birds with mother, one-inch mesh should be used. Don't stretch the wire too tightly, otherwise the birds may injure themselves by flying against it. There is an entrance door in the shedded with other doors leading through the shedded pait part of each partition from pen to pen. Have a lock for the entrance door with hook and eye fastening on the inside. Don't leave doors unfastened any longer than absolutely necessary to pass through. Pheasants are as quick as lightning.

Use a good motherly hen to hatch your pheasants, and for this purpose the Cochin bantam has no superior. Don't use an incubator. If a bantam hen is used set her on from 9 to 12 egzj. Put her in a nest where she will not be disturbed and treat as if on ordinary eggs until the 22nd day. For a nest make a box 14 inches square (bottom) 18 inches high in front, and 14 inches 
in back. Across the front, beginning at bottom nail on a board 3 inches wide; within 2 inches of the top nail across another board the same width. This leaves a space 12 by 14 inches. Next take a board to fit this opening and fasten it to the bottom 3 inch board with a hinge so it will act as a dorr and open down. Place fastening at top to hold it closed. When opened down this door forms an approach for the hen to get back into the nest after she has been off to feed. It is advisable to connect several nests together using one board for coutinuous top, bottom and back. If nest is to be left outside, the top should extend over a few inches in front and back. To make the nest proper, first place two inches of clean damp dirt in the bottom of the box and on this arrange some soft straw or grass hay as for chickens. The number of nests will of course depend on the number of pheasant hens you have. Place the nests around the sides (inside) of a house or enclosed pen provided with a watering cup. Each day at a regular hour, place feed in the house or pen, open the doors to the nests, and see that the hens all come off. After they have eaten and had a drink, which will occupy about twenty minutes time, they will return to the nests when the doors should be shut and left for another day. If possible provide a dust bath for the hens in addition to their food and water.

The eggs keep as well as chicken eggs and it is a good plan to set several hens at once if you have the eggs. Always keep a record of the dates when hens are set that you may know when to expect the young 
birds. Pheasants will hatch about the 23rd day, and all the eggs under each hen hatch at the same time. The disposition is to leave the nest immediately, hence the added advantage of having the hen locked up. Ds not remove the young pheasants from the nest until 24 hours old. Remaining under the hen gives them strength. At the end of this period remove hen and pheasants to a box about 18 inches by 3 feet in size and place where it can have the benefit of the sun. Provide a shade for part of the box. Sprinkle the bottom thickly with sand, give water in small fountain and cover box with a piece of wire netting. The object of this box is to keep the young pheasants near the foster mother until they learn her call, the small size of the box keeping them always near her. Have ready a runway made $1 \times 2 \times 5$ feet in size, the ends made of boards $1 \times 2$ feet strengthened by cleats nailed across the grain, these ends connected by four strips $1 \times 3$ inches and the whole covered with a strip of 5-foot 2 -inch mesh poultry netting stretched tight (see photograph). It may here be remarked that for fastening poultry neiting, I have found No. 11 double pointed tacks well adapted. Make a box 2 feet square with top hinged in back as shown in photozraph and opening in front to correspond with opening cut in one end of luaway for a coop. The front of this coop should be slightly higher than runway. Place the two together as seen in photograph. Place this coop and runuay in large pen so as to receive protection of shed but so that runway may have benefit of morning sun. After the hen has been kept in box four or five days re- 


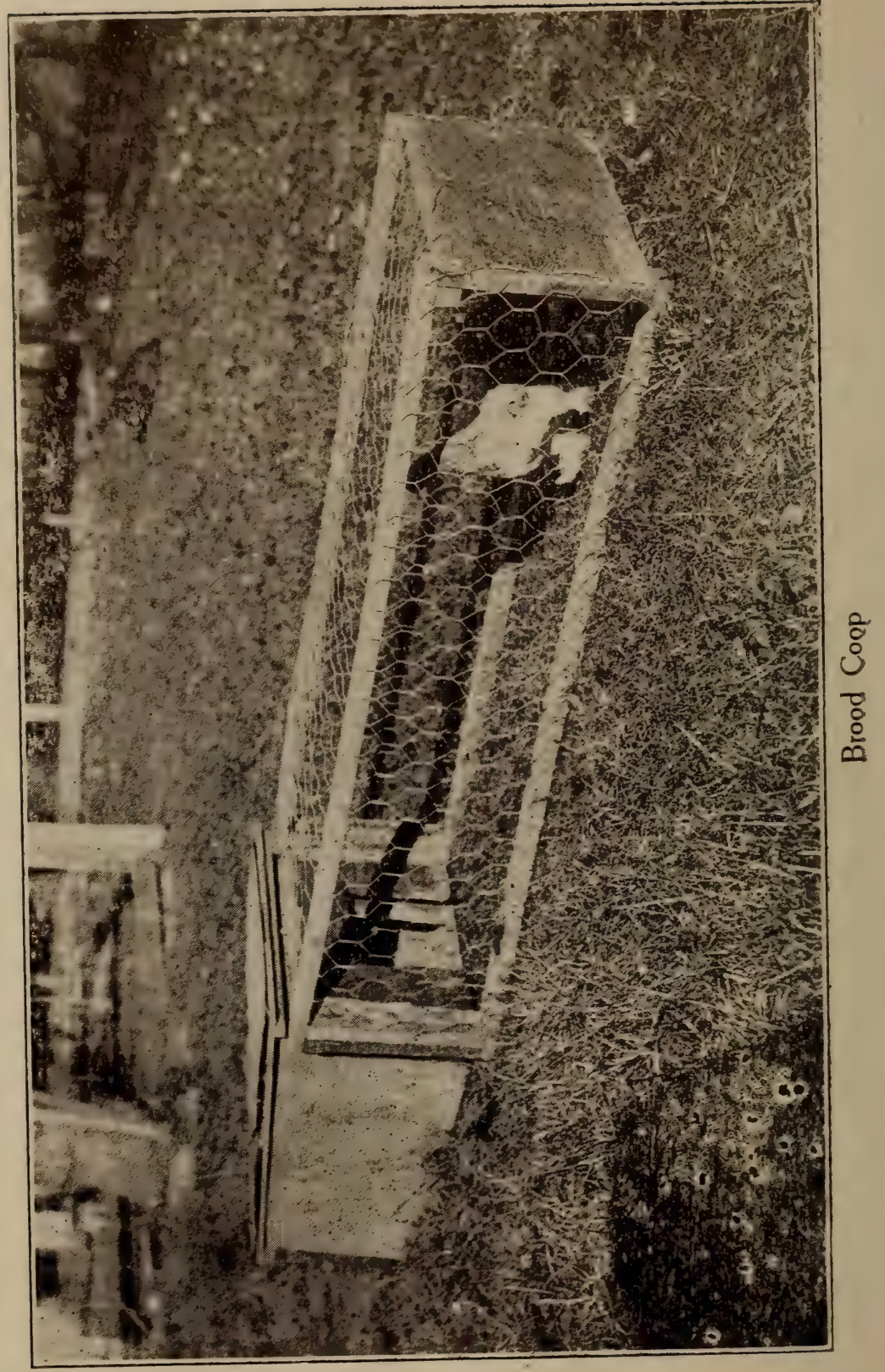


move her and pheasants to this coop. Make this change at twilight and see that all the pheasants go under the hen before leaving them. A wire screen may be slipped between the coop and runway as a precaution against the pheasants getting out the first night. It should be removed early in the morning. The change if made in the day greatly alarms the small birds. The wire runway prevents the hen wandering about and if a bantam she will be continually hovering. The small pheasants can easily pass through the 2-inch meshes, besides the pheasants can be fed food different from the hen. In about two months you will notice that the pheasants are no longer roosting under the hen, but are huddling together in corner of pen outside. It is now time to remove the hen as they will never return to her.

Place a drinking fountain outside of runway but so hen may reach it. Drinking fountains as shown in the illustration sh o uld be used. Always keep drinking water before your pheasants and in warm

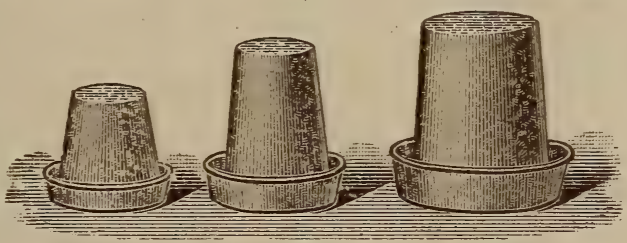
weather see that it is changed daily. Cleanliness is essential. Your hens should not have lice, but if you have cause to fear them, when the young pheasants are taken off the nest, grease the top and under part of each one's head with vaseline or olive oil. The latter may conveniently be applied with a sewing machine oiler. When the hen is placed in the nest, dust her feathers thoroughly with buhach powders and give her another dusting a 


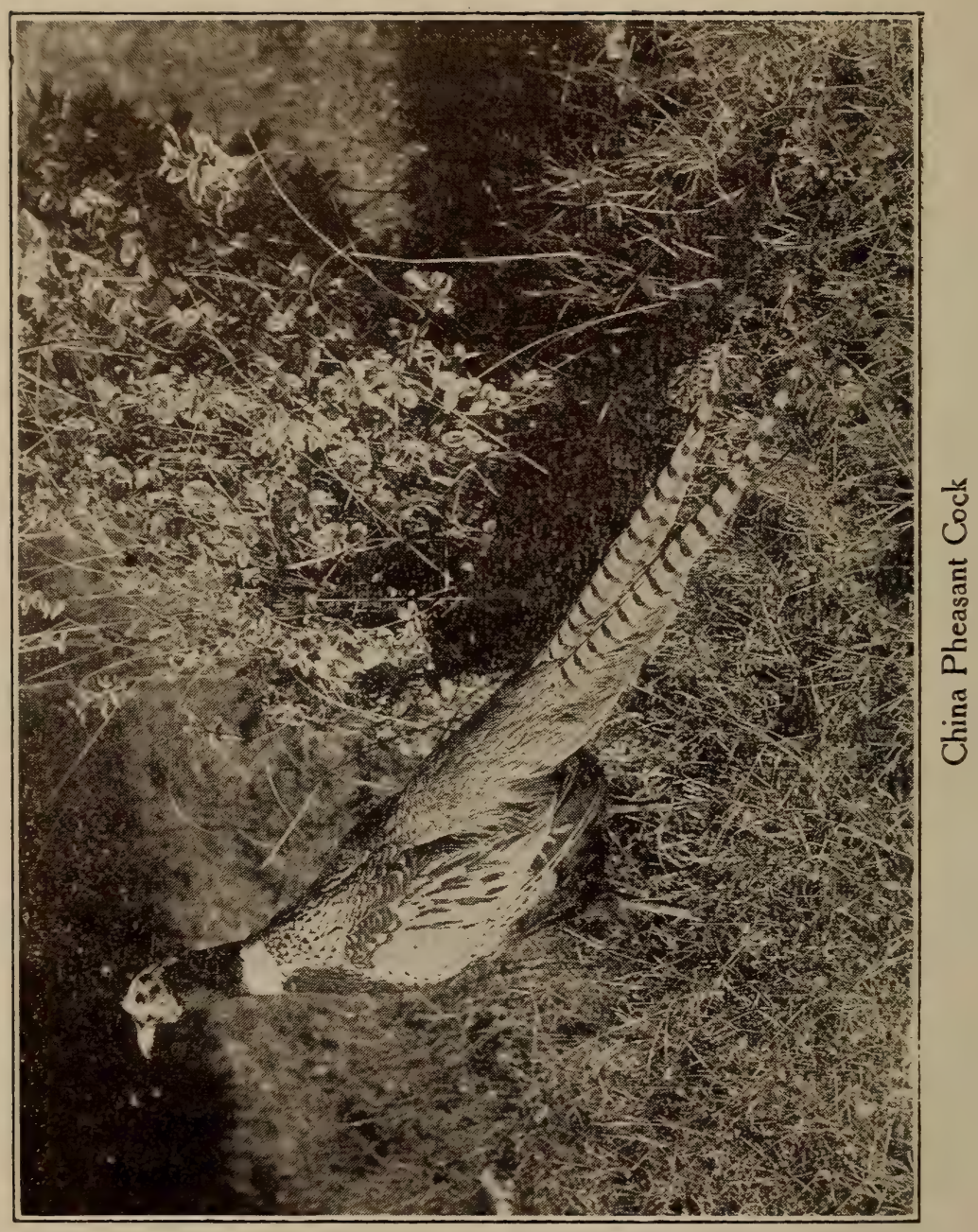


few days before time to hatch. If eggs get foul, wash them with tepid water while hen is eating. Early in the season give each hen 10 or 12 birds; later the number may be increased to twenty. As with chickens the important item is the feed. When the birds have been removed from the nest to box, give them a little chopped lettuce or tender cabbage or rape, preferably the lettuce, and a small amount of this ration should be given them daily. Also feed hard boiled egg, shell and all, chopped up and crumbled with rolled oats or corn meal. Feed the mother hen wheat, but feed the little pheasants four times a day with the egg mixture. Feed but a small amount each time and feed it to them fresh. Stale egg mixture or too much egg, means fowl trouble. After a week they may be fed only three times a day. The egg mixture may be alternated with fine ground lean meat rubbed with shorts until crumbly. Too much meat will cause leg weakness. Keep Diamond Chick food before them all the time. They may also be given a small amount of boiled rice and curd occasionally. After birds are one month old, keep cracked soft wheat or chick food before them all the time and until three months old feed them sparingly fresh hamburger steak crumbled with shorts once a day. After this give whole soft wheat and gradually reduce meat diet until when five months old the meat may be omitted, however it is advisable to give your pheasants an occasional feed of meat and particularly during the laying season. Give the growing pheasants all the green food they will eat: In addition to the greens mentioned above they are ond of mangels and carrots. 
By soft wheat is meant the soft varieties of wheat as distinguished from the hard varieties. While the pheasant is omnivirous, still insects are especially relished. In the wild state they seem to feed uron the seeds most available. In China they frequent the millet fields, and an examination of the crops of a large number of birds killed in Oregon, disclosed a large variety of grains and seeds with a large percentage of bugs.

For feeding young pheasants, the most successful results have been obtained with the larvæ of the comnon blue fly (maggots). When this food is used nothing else need be fed, except greens occasionally, until the birds are a month old, however the chick food or cracked wheat should be kept before them that they may learn to eat it and be prepared to adapt themselves to the whole wheat diet when the larvæ food has been discontinued, which should be done gradually.

The objection to the larvæ food is the offensive odor ordinarily associated with it. This may be overcome by raising the larvæ scientifically. Contrary to this commonly accepted idea, the larvæ of the fly prefers fresh to decaying meat. Prof. M=Gillivary of $\mathrm{Qu} z e n s$ Uaiver sity, Toronto, who has successfully raised English Ring-neck pheasants, says: "Our investigation and study of entomology prove to us that maggots separated from their usual surroundings, are just as clean and odorless as young chickens. Flies do not lay their eggs on tainted meat when fresh meat can be found, and maggots are clean feeders from choice and thrive best on fresh meat." If the following method is employed, there will be lit- 


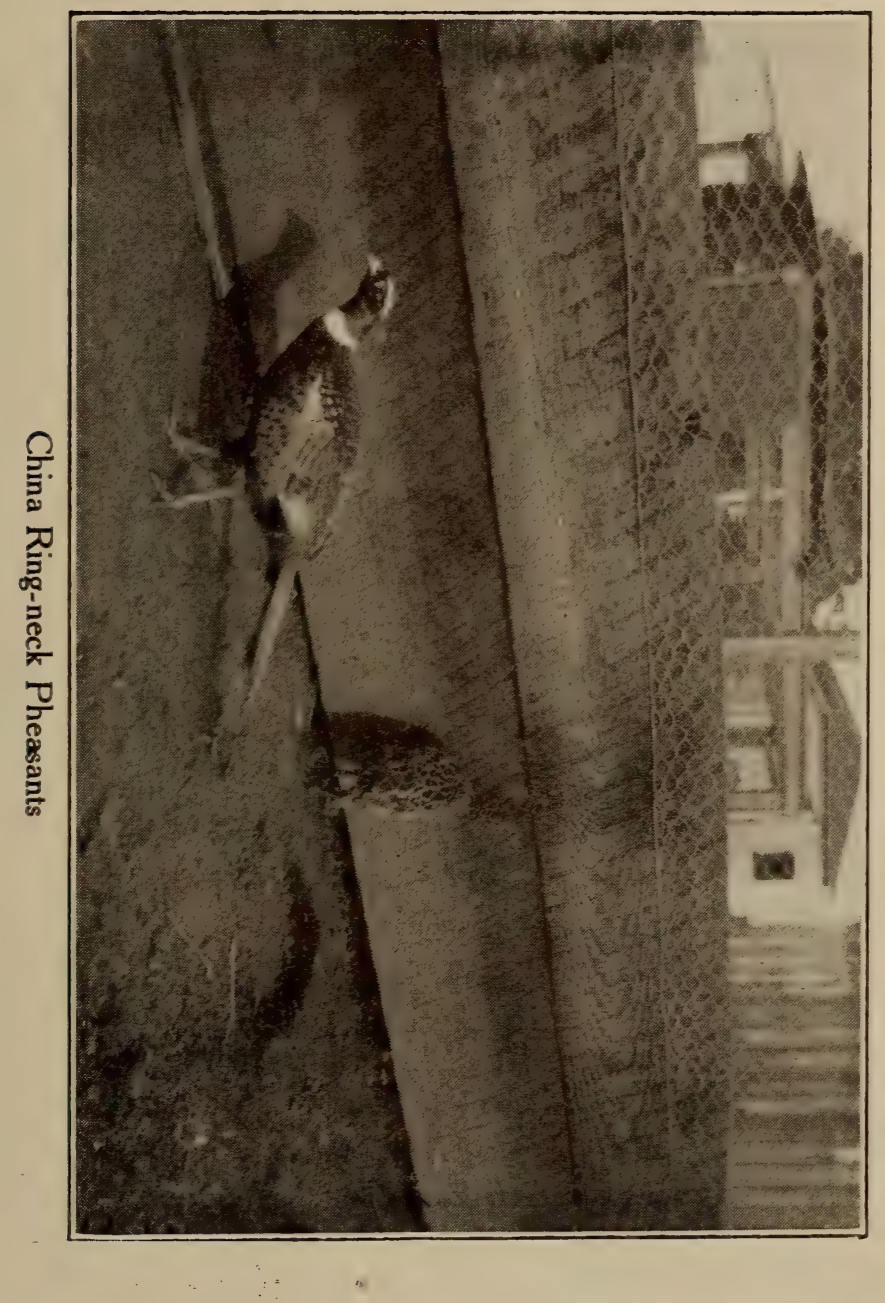


tle or no odor. Secure a quantity of green bone and meat trimmings coarsely ground together. Take a tin pan with straight sides at least three inches deep and cover bottom with shorts or fine dirt. On this place the bone and meat mixture and leave where the flies may have access to same. In warm weather the fly eggs will hatch in about two days time and the bone mixture will be partially dried up. The larvæ are adverse to strong light and will be found to have gone to the dirt or shorts. They must now have something to feed upon. Remove the bone mixture and place thin slices of fresh liver on the shorts or dirt. Turn the bone mixture back on top of the slices of liver. In a few hours the larvæ will all leave the bone mixture and be under and feeding upon the liver. After this the bone mixture should be thrown away.

In a day's time the liver will be eaten to shreds and must be replaced with a fresh supply of thinly sliced liver or fresh meat, and so on each day until the larvæ are practically full grown. This will take practically a week's time and they may then be fed to the young pheasants. The larvæ must be fed on liver or meat as long as they are on hand. As soon as they are matured they will decend into the shorts or dirt and change into the pupa state, in which condition they are equally as good for feed as when alive. In feeding the liver or meat, feed only enough that they will consume it in 24 hours time. "The assimilating power of the larvæ is so great that it can change every particle of meat or liver (except fibre) to larvæ, consequently there can be no 
smell." The object in cutting the liver or meat thin is that it may all be cousumed before having time to become tainted. Keep extra supply of liver in cool place and a little charcoal such as is used to feed chickens, sprinkled over and under it will tend to keep it fresh.

In order to keep a supply of larvæ, it will be necessary to put out new pans of bone every few days depending on quantity, the number of pheasants you have and the state of weather. The warmer the weather the more rapid the development of the larvae. If you contemplate using larvæ, you should start with the bone mixture a week prior to date of first hatching.

The advantage of this food is that you need not hesitate to feed young birds all they will eat. They are wild for it and will frequently crowd their crops and throats to overflowing with no apparent bad results. They thrive better on this food than on anything else. Other methods may be employed to produce the larvæ but it should be remembered that but 15 days time elapse from the laying of the fly egg until it has successfully become larvæ, entered the pupa state, and turned into a fly again, that the larvæ are clean feeders and that they must have a medium (shorts, or clean fine dirt, perferably) in which to bury themselves. When about ten days old they pass into the pupa state in which form they may be kept if stored at a low temperature (40 degree F.) The low temperature stops the development.

Ever yone is familiar with the history of the butterfly, how an ugly worm dries up in the fall of the year and in springtime breaks open to release a beautiful butterfly. 


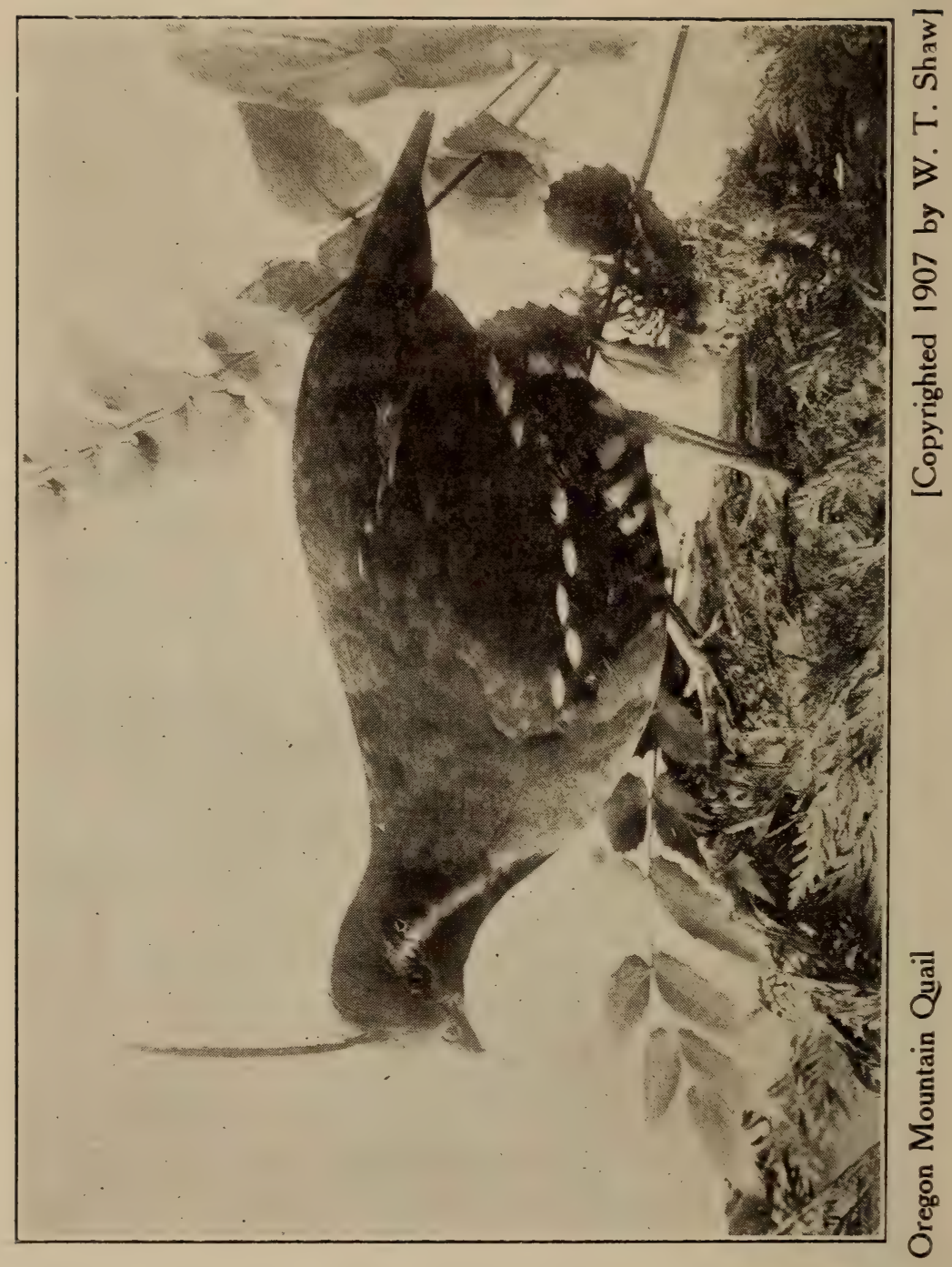


This dried worm is the pupa, and just as the butterffy's egg dries up and later produces a perfect insect, so the larvæ of the common fly when grown dries up and later produces a fly again, only the change to the fly is accomplished in a few days instead of months.

Should the pan of shorts or dirt become heated it means that the larvæ are too crowded and will leave if possible. A part should be removed to another pan or given a larger proportion of shorts or dirt. With facts above, your own ingenuity and some experience will suggest convenient methods for producing larvæ.

The true pheasants (Phasianus) will breed the following spring after hatchings, while the male birds of the Golden, Amherst, Silver and Swinhoe are not in full plumage until the second year. The first two will breed at a year old but the latter two not until two years old. Silver and Swinhoes should be mated in pairs. For stocking purposes, pheasants should be liberated in pairs.

Birds are shipped by express in slatted crates covered with burlap and take single merchandise rate. From one to four may be shipped in one crate the whole weighing about 25 to 26 pounds, depending on number of birds. I provide the crate with food, a cup for water and affix permit for shipping with printed instructions to express agent. Eggs are shipped in improved crates. (See illustration). My advise to persons desiring to engage in pheasant breeding is to buy a trio, but in any event try a setting of eggs even if you let the pheasants go when they are large enough to care for themselves. The pleasure derived will repay you for all expense and trouble. 


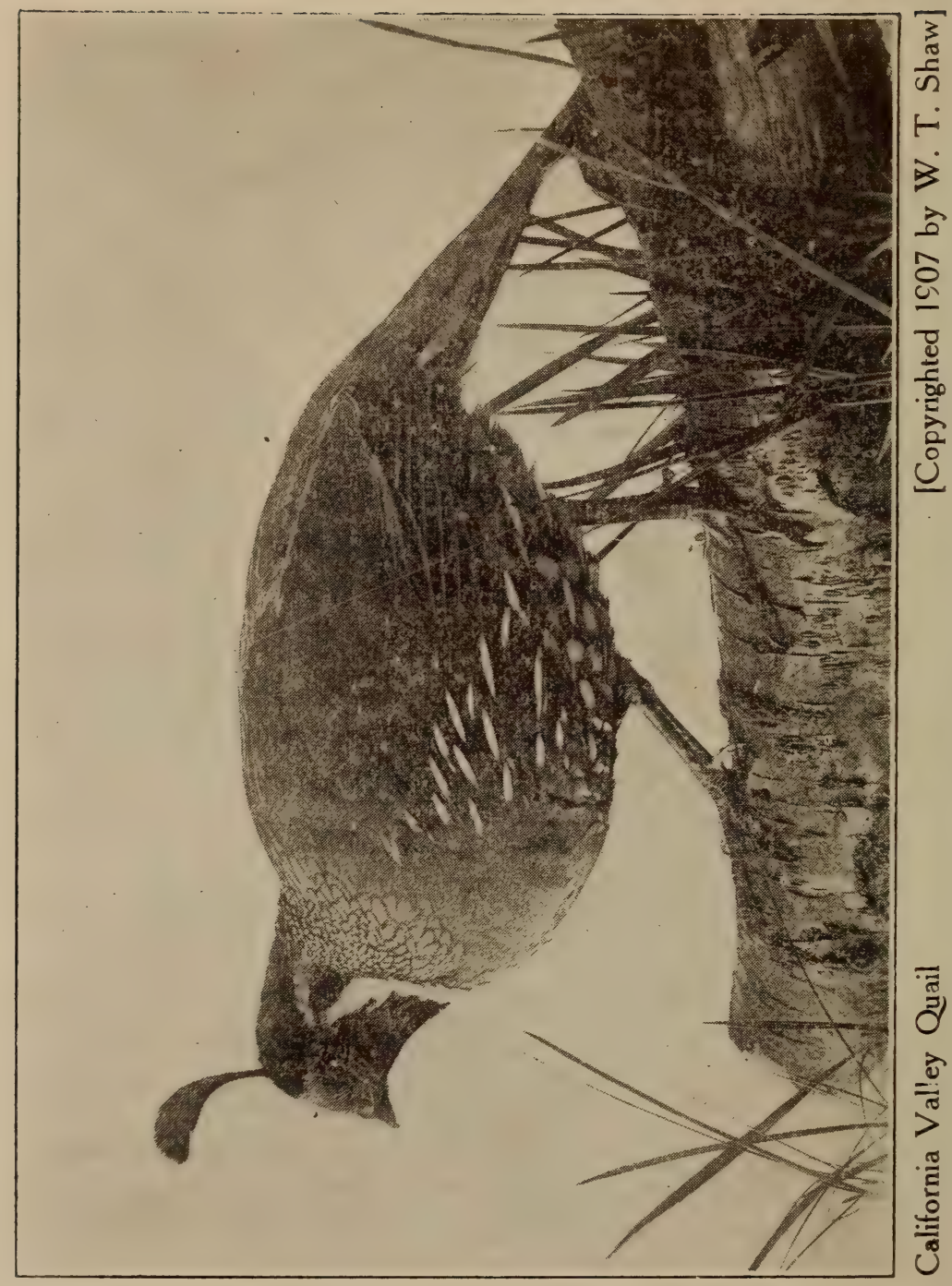




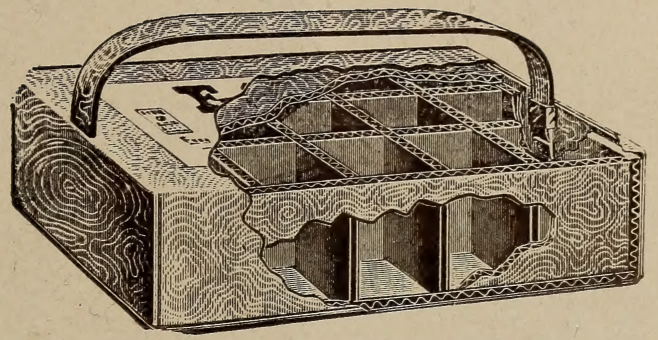

Patent Crate for Shipping Pheasant Eggs

By inquiring of your local express agent you can ascertain the cost of transportation on either live birds or eggs, but bear in mind that the birds go as single merchandise, slatted crates. I guarantee that the birds will be delivered to the Express Company in Corvallis in first class order. Cut of one shipment of 100 birds to the state of Kansas from Corvallis, Oregon, only one bird died.

I am asked to reccmmerd a variety to the tyro. This is difficult to do. So far as the raising is concerned there is little difference. The question of beauty is one of opinion. Personally, I regard the Golden and Chinese the most beautiful, but the Golden as already stated, does not put on his fine plumage until the second year.

It is well to clip the wings of the birds when about two or three weeks old. To do this, use care, extend the wing fully and cut each pinion feather from middle of wing outward, cutting between shaft and quill. Do not cut the remaining feathers or you will leave the lungs unprotected. The pinion or flight feathers are the coarse feathers near the tip of the wing. I also advise pinion- 
ing pheasants where they are kept in aviaries. This does not injure their looks, as the absence of the flight feathers is unnoticed, and the birds cannot injure themselves by striking against wire, and also has the added abvantage of permitting birds to be kept in yards enclosed by a six or eight foot fence only, eliminating the cost of wire covering overhead. The operation requires no skill and consists in clipping off the wing at the first joint with a sharp pair of scissors. It may be performed at all ages, but the best time is when they are about two weeks old.

To catch pheasants use a net similar in shape to a fisherman's landing net but made of material similar to domestic, and provided with a four foot handle. In handling the birds don't hold by leg or wing. The wing bone particularly, is very fragile and a broken wing or leg will result if you are careless in this regard.

In the introduction of the pheasant Oregon is the pioneer. The success that has followed the venture has encouraged her neighbors on the North and East, Washington and Idaho, to follow her example. Last year 1000 pheasants were shipped from Oregon to the state of Washington, and more are ordered for the coming season. Kansas, Illinois, Colorado and Minnesota are working toward restocking with pheasants, and $\mathrm{Cal}$ ifornia is seriously considering the matter.

The pheasant industry has come to stay, and the writer ventures the assertion that before many years the pheasant will be known in every state in the Union.

Why not be one of the pioneers yourself, and in addition to the pleasure and profit you will derive, have the satisfaction of being responsible for their introduction into your own state. 


\section{Portland Seed Company's}

Diamond Brand

\section{Chick Feed}

The Kind it Pays to Feed

Endorsed by all Poultrymen

\section{A Complete and Perfectly Balanced Ration That Will Make Pheasant, Quail and Chicks Grow and Keep Them Healthy}

This Chick Feed of ours is just such a food as the old hen would find for her babies if she had free range on the farm. That's why it's so successful. By using Diamond Chick Feed you are giving the Chicks just what nature intended they should have, a food composed of grains (cracked), small seeds, grit, bone, dried sweet meat, (to take the place of insects and bugs), charcoal, etc., mixed in the right proportion to produce a quick, and profitable growth without loss. It's so convenient, so handy, always ready for use, and you can raise so many more chicks by feeding it that it is the cheapest feed you can buy. No drooping wings, weak legs or bowel trouble when you feed "Diamond Brand" Chick Feed.

\section{Reduced Prices}

5-lb pkg., 25c; 15-lb pkg., 50c; 25-lb sack 90c; 50-lb sack $\$ 1.60 ; 100$ lbs., $\$ 3.00$

We are Headquarters for Poultry Supplies of All Kinds Our Catalog Tells All-Free on Request

\section{Portland Seed Co.}

Portland, Oregon

Spokane, Washington 


\section{LIBRARY OF CONGRESS}
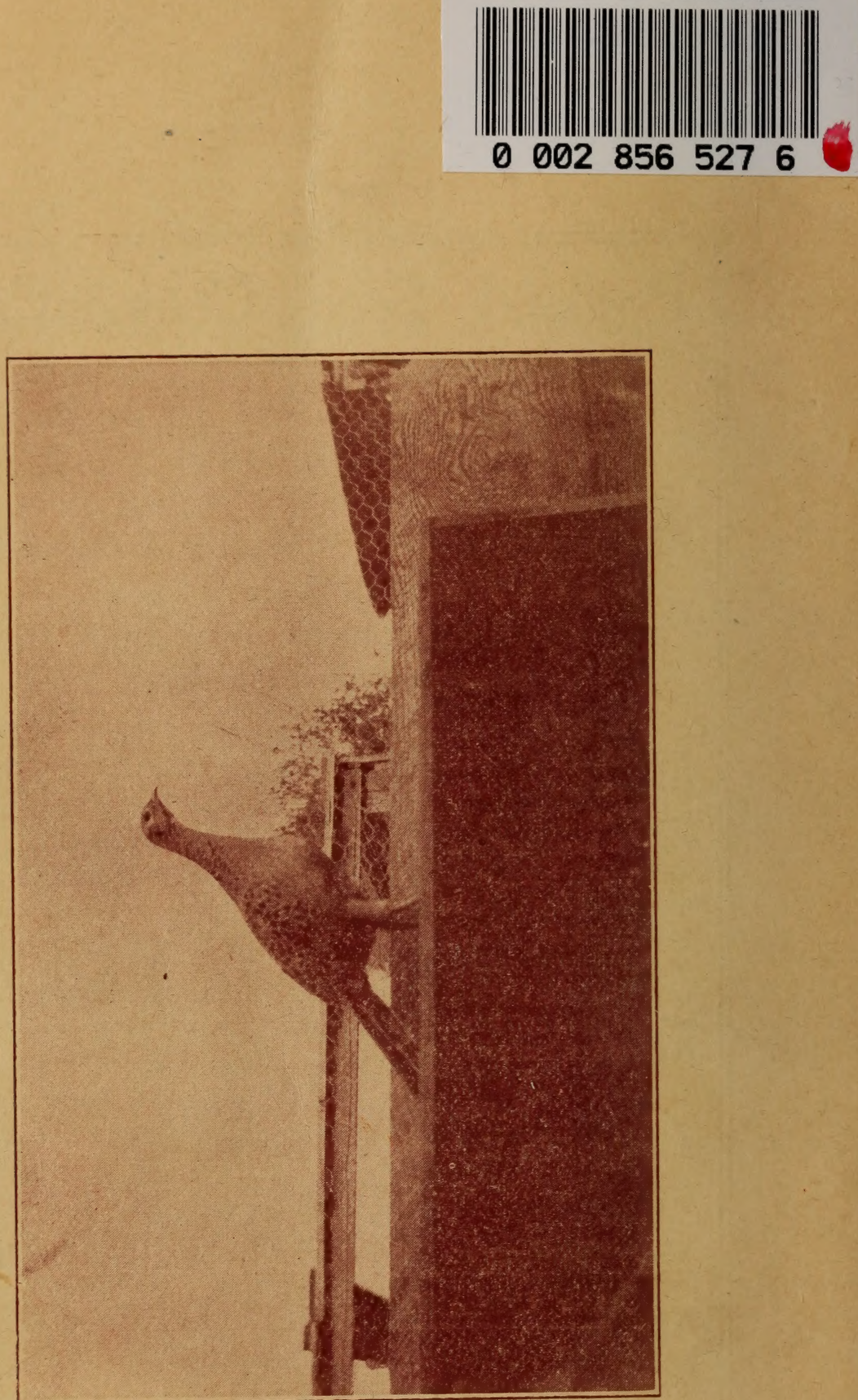